\title{
La consignación y toma de posesión material por expropiación como gestión de jurisdicción voluntaria: ¿una garantía adecuada de defensa de los derechos e intereses del expropiado?
}

\section{The management of consignment and material possession by expropriation. Its review based on the fundamentals of voluntary jurisdiction and the defense of the rights and interests of the expropriated}

El presente artículo trata del procedimiento de consignación y toma de posesión material por expropiación en Chile, definido tradicionalmente como una gestión de jurisdicción no contenciosa; a fin de establecer en qué medida posee esa naturaleza $y$, si así definido, ofrece una garantía adecuada de defensa de los derechos e intereses del expropiado.

Palabras clave: Consignación, expropiación, jurisdicción voluntaria.
This article deals with the procedure for consignment and taking of material possession by expropriation in Chile, traditionally defined as a noncontentious jurisdiction management; in order to establish to what extent, it has that nature and, if so defined, it offers an adequate guarantee of defense of the rights and interests of the expropriated.

Keywords: Consignment, expropriation, non-contentious judicial procedure.

\footnotetext{
" Profesor de Derecho Administrativo. Escuela de Derecho, Universidad de Tarapacá, Arica, Chile. Doctorando en Derecho, Universidad de los Andes, Chile. Abogado, Licenciado en Ciencias Jurídicas de la Universidad de Tarapacá. Magíster en Ciencias Jurídicas, Universidad de Tarapacá. Dirección postal: Cardenal Caro N³48, Arica, Chile. Correo electrónico pponce@academicos.uta.cl.

Agradezco a los profesores Jaime Arancibia Mattar y Alejandro Romero Seguel, así como a los árbitros de la revista, por sus valiosos aportes y comentarios críticos, todos los cuales contribuyeron enormemente al desarrollo del presente trabajo.
}

Artículo recibido el 28 de octubre de 2019 y aceptado el 25 de mayo de 2020. 


\section{Introducción}

La expropiación, entendida como un mecanismo potestativo por el cual el Estado priva a un particular del dominio sobre un bien determinado para satisfacer necesidades de utilidad pública o de interés nacional, bajo condición de indemnizar el daño patrimonial causado al afectado; es un instituto que se encuentra históricamente arraigado en nuestro sistema jurídico, aunque parece no tener un origen preciso'.

Son diversos los estudios que abordan aspectos históricos y sustantivos ligados al ejercicio expropiatorio, principalmente destinados a identificar sus elementos esenciales y límites. En la doctrina nacional, dichas particularidades, con mayor o menor detención, bajo el régimen normativo vigente, han sido tratadas especialmente en el ámbito constitucional y administrativo².

No obstante, un aspecto que parece menos estudiado en Chile es el que refiere a su concreción procedimental ${ }^{3}$. Ello guarda directa relación con

\footnotetext{
1 Para algunos autores, los antecedentes más antiguos de expropiación se encuentran en la Biblia. Se sostiene que el Libro I de Las Crónicas, Capítulo 21, versículos 22 y 23 relata un caso de expropiación. Vid. Drago 1949, 3; así también Casas y Romero Villanueva 2014, 10. Marienhoff alude a éste y otros pasajes bíblicos, pero precisa que se trata más bien de "vestigios" de expropiación. Vid. MARIENHOFF 1998, 144.

También se suelen citar procesos expropiatorios desarrollados en la antigua Grecia (Vid. DraGo 1949, 4; Reynolds 2010, 15; Casas y Romero Villanueva 2014, 11) y en el derecho romano (Vid. Drago 1949, 4; Lozano Corbi 1995, 123-129; Marienhoff 1998, 145; Ponte 2008, 254; y ReynoldS 2010, 16). La doctrina nacional tiende a situar la aparición de la expropiación en la Edad Media (Vid. Soto Kloss 1996, 233; Fuentes Olmos 2018, 28).

Si bien se suelen datar casos de expropiación en el régimen feudal y el absolutismo (Vid. Drago 1949, 5; Reynolds 2010, 46; Fuentes Olmos 2018, 72), en el antiguo derecho español (Vid. MARienHofF 1998, 146; Casas y Romero Villanueva 2014, 11) y en el derecho indiano (Vid. Dougnac Rodríguez 1994, 328); dicha opinión es refutada por algunos autores, para quienes el régimen de propiedad en tales períodos, de carácter público y no liberal, resulta incompatible con la noción actual de expropiación (Cfr. López-NIETO y MAYO 2007, 67; CASTÁn TOBEÑAs 1992, 429).

En todo caso, existe consenso en sostener que la expropiación aparece claramente consagrada, con sus elementos esenciales vigentes, a partir de las normas estatutarias europeas modernas de fines del siglo XVIII y comienzos del XIX, como la Declaración de los Derechos del Hombre y del Ciudadano y la Constitución de Cádiz.

En Chile, la potestad estatal de privar a un particular de su propiedad es reconocida constitucionalmente ya en el artículo 9 , Título I, Capítulo I, del Proyecto de Constitución Provisoria de 1818. La expropiación, como tal, aparece propiamente en el artículo 117 de la Constitución de 1823.

2 Así puede verse por ejemplo en: Ríos Álvarez 1978, 47; Cea Egaña 1988, 194; Silva Cimma 1995, 301; Evans de la Cuadra 1999, 373; Caldera Delgado 2001, 367; Verdugo Marinkovic et al. 2002, 312; Vivanco Martínez 2006, 461; Aldunate Lizana 2006, 285-303; Fermandois V. 2010, 384; Ponce Correa 2011; Cea Egaña 2012, 581; Nogueira Alcalá 2013, 193; Matute E. 2014; .Bermúdez Soto 2014, 583; Jiménez Larraín y Jiménez Loosli 2014, 441; Ponce De León Salucci 2015, 293-324; Cordero Quinzacara 2015, 309-335; Navarro Beltrán 2016, 313; Fuentes Olmos 2018, 355; Quezada Rodríguez 2018, 87-122; Guiloff Titiun 2018, 621-648; y Celis Danzinger 2019, 913, entre otros. Dentro de las pocas obras que, al menos a nivel monográfico, abordan este instituto desde la óptica del derecho privado bajo el sistema previsto en la Constitución Política de la República de 1980, podemos mencionar a PeñalLILlo Arévalo 1995. A ello cabe agregar la delimitación conceptual de este instituto en Montory Barriga 2019, 95.

3 Entre los trabajos publicados en Chile que refieren especialmente al aspecto procedimental de la expropiación podemos destacar: Rios Álvarez 1978; Morales Gana 1999; Peña Mardones 2001;
} 
la defensa de los derechos e intereses de los afectados pues, dada la irresistibilidad ínsita de todo proceso expropiatorio, tal tutela pasa precisamente por asegurar el cumplimiento de los presupuestos y condiciones a que se sujeta su ejercicio. La intervención judicial se traduce, entonces, en un control del ejercicio ablatorio.

Este último punto parece haber sido advertido por el Constituyente, el cual, a falta de acuerdo, somete la actividad administrativa expropiatoria a un control judicial forzoso. Así, a no ser que medie consentimiento expreso del expropiado, lo que supone -en los hechos- la ausencia de controversia entre las partes, la entidad expropiante está obligada a solicitar autorización judicial para tomar posesión material del bien.

Si bien la judicialización de los procedimientos expropiatorios y subsecuente control jurisdiccional puede verificarse por diversas vías, la gestión de consignación y toma de posesión material se muestra como la de mayor importancia práctica. Máxime si advertimos que, al alero de este procedimiento, se desarrollan otros trámites relevantes, como la recolección de frutos pendientes, la liquidación y pago de la indemnización o la inscripción del bien expropiado.

Ahora, pese a que la apropiación coactiva de la propiedad privada lleva ínsita una colisión de derechos e intereses de -al menos- expropiante y expropiado, lo que pudiera suponer, muchas veces, una controversia entre ambos; el principal procedimiento destinado a materializar la expropiación ha sido calificado, tanto por la doctrina como la jurisprudencia, como una gestión judicial de carácter no contencioso.

Dicha calificación, permanentemente reiterada por los más de cuarenta años de vigencia del procedimiento previsto en el Decreto Ley $N^{\circ} 2186$, parece zanjada. No obstante, se aparta de la noción de jurisdicción voluntaria construida tradicionalmente en Chile a partir de la definición del artículo 817 del Código de Procedimiento Civil, entendida como una gestión judicial en la que no se suscita contienda alguna entre partes.

En esta línea, el presente trabajo busca sostener que la definición de un procedimiento como voluntario obedece a una cuestión normativa y no casuística; una técnica legislativa que opera ex ante, con independencia de la existencia efectiva de un conflicto jurídico particular. El elemento esencial de esta categoría sería la ausencia de un emplazamiento concreto de los eventuales afectados o interesados.

Pero, para que dicha opción legislativa resulte admisible, el sistema debe consagrar garantías jurisdiccionales que, con todo, ofrezcan una adecuada defensa de los derechos e intereses involucrados en caso de conflicto entre el solicitante y los eventuales afectados. Ello exige el otorgamiento de

Ponce Correa 2011. También abordan el procedimiento expropiatorio Bermúdez Soto 2014, 593 y Celis Danzinger 2019, 920. 
vías idóneas para tomar conocimiento, cautelar, discutir y resolver la contienda, sea al interior del mismo procedimiento o iniciando uno diverso.

Por esta razón es que, luego de revisar la consignación y toma de posesión material desde la óptica de una gestión judicial que carece de emplazamiento concreto de los eventuales afectados e interesados, analizaremos si tal diseño procedimental ofrece al expropiado una posibilidad adecuada de defensa de sus derechos e intereses, para identificar sus puntos críticos.

Comenzaremos por revisar brevemente la regulación del procedimiento expropiatorio en Chile, a fin de precisar el lugar que ocupa dentro de éste la gestión de consignación y toma de posesión material. En segundo término, buscaremos delimitar la noción de gestión no contenciosa en el sistema nacional, para luego esbozar un criterio diferenciador de esta clase de procedimientos por la vía de determinar sus características esenciales.

Finalmente, demostraremos que el procedimiento de toma de posesión material y consignación responde efectivamente a la noción de gestión voluntaria planteada, que el sistema reconoce al expropiado adecuadas vías de defensa de sus derechos e intereses, pero que aparecen algunos problemas importantes a la hora de hacerlas valer.

\section{El procedimiento expropiatorio vigente en Chile}

1. Marco normativo. Decreto Ley $N^{\circ} 2186$ y el fin de la multiplicidad de procedimientos expropiatorios

El procedimiento expropiatorio vigente se encuentra regulado esencialmente en el Decreto Ley $N^{\circ} 2186$ de 1978. Se trata de la primera ley general de procedimiento que alcanza verdaderamente el objetivo de regular la totalidad de expropiaciones que se verifican en nuestro país.

En efecto, uno de los problemas advertidos por la Comisión Ortúzar, órgano que elaboró el respectivo proyecto de decreto ley a partir de la propuesta presentada por la Subcomisión de Derecho de Propiedad ${ }^{4}$, radica en la existencia a esa época de una gran variedad de procedimientos expropiatorios vigentes, así como la imposibilidad histórica de contar con un mecanismo único para estos fines ${ }^{5}$.

Desde el primer intento de ley general de expropiaciones, dictada el 14 de agosto de 1838, la ley de 18 de junio de 1857 y el propio Título XV, del Libro IV del Código de Procedimiento Civil _-todas normas con cierta vocación de generalidad-, terminó siempre imponiéndose la práctica de dictar normas

\footnotetext{
4 Vid. Actas oficiales de la Comisión de Estudio de la Nueva Constitución, sesión $246^{a}, 21$ de septiembre de 1976.

5 Sobre la multiplicidad de procedimientos expropiatorios y la escasa aplicación del Código de Procedimiento Civil vid. Ríos Álvarez 1978, 9; así también Ponce Correa 2011, 99.
} 
especiales. Así, los derechos de los expropiados fueron radicalmente distintos según la norma que regía cada expropiación ${ }^{6}$.

Para adquirir el carácter de norma procedimental única de expropiaciones, el artículo 41 Decreto Ley N² 2186 derogó orgánicamente todas las leyes prexistentes en esta materia, aún en lo que no le fueren contrarias. Ello, si bien evitó la supervivencia de procedimientos disímiles, no inhibe al legislador para dictar normas especiales, habiendo establecido metodologías específicas para el cálculo de la indemnización en algunos casos ${ }^{7}$.

El Código de Procedimiento Civil conserva un carácter supletorio ${ }^{8}$, a excepción de su Título XV, del Libro IV, el cual debe considerarse derogado?. Esta supletoriedad deriva ya de su remisión expresa en el artículo 40 y otras disposiciones del decreto ley, como de la existencia de vacíos normativos evidentes que resulta necesario suplir, recurriendo para ello al carácter de ley general que ostenta el código.

Ahora, pese a la uniformidad procedimental que ofrece, debemos advertir que el Decreto Ley $N^{\circ} 2186$ se trata de una norma antigua, anterior a

\footnotetext{
6 En el informe de 14 de octubre de 1977, presentado por la Secretaría de Legislación con ocasión de la tramitación del Decreto Ley $N^{\circ}$ 2186, se da cuenta de la existencia de, al menos, 19 procedimientos expropiatorios diversos, informados por la Biblioteca del Congreso Nacional. Algunos de ellos otorgaban al expropiado derecho a reclamación judicial o, incluso, exigían la suscripción de una escritura pública, en tanto que otros contemplaban una tramitación exclusivamente administrativa. El cálculo de la indemnización y su forma de pago también diferían en cada norma y algunas de éstas contemplaban regímenes abiertamente excesivos. Uno de los procedimientos más criticados en esta materia fue el de la reforma agraria, que garantizaba el pago solo de un $10 \%$ de la indemnización en efectivo y permitía prorratear el saldo en cuotas hasta por 15 años, sin reajustabilidad.

7 Así por ejemplo, el artículo $11 N^{\circ} 3$ de la Ley No 18.097, Orgánica Constitucional sobre Concesiones Mineras (D.O. 21 enero 1982) establece reglas especiales para el cálculo judicial de la indemnización respecto de la expropiación de una concesión de explotación. En otro ámbito, referido también al cálculo del daño patrimonial, el artículo 88 de la Ley General de Urbanismo y Construcciones, modificado por la Ley Nº 20.791 (D.O. 29 octubre 2014), prevé un régimen especial en las expropiaciones parciales, por el cual permite rebajar de la indemnización aquella plusvalía que el inmueble adquirirá en virtud de la obra pública que motiva su adquisición.

${ }^{8}$ Se han estimado aplicables, por ejemplo, las normas sobre el recurso de casación previstas en Título XIX del Libro III, incluso al punto de llegar a declararse la inaplicabilidad del inciso $2^{\circ}$ del artículo 768, a fin de no entender limitadas las causales de casación en la forma. Vid. Sentencias TC Roles No 3008 (2016), No 5257 (2019) y No 5937 (2019). Cabe advertir que, con anterioridad a dichas sentencias, el Tribunal Constitucional había rechazado un requerimiento de inaplicabilidad similar, por empate de votos. Vid. Sentencia TC Rol No 2904 (2016).

9 "[...] En efecto, el artículo 41 del este D.L. dispone que 'Desde la fecha de vigencia de la presente ley, quedan derogadas todas las leyes preexistentes sobre las materias que en ella se tratan, aun en la parte que no le sean contrarias'; [...] Que, en tales condiciones, han perdido vigencia en esta materia las normas sobre expropiación del Código de Procedimiento Civil [...]". Inversiones Piedra Roja Limitada con Fisco de Chile (2005).
} 
la Constitución de $1980^{10}$, que permanece casi sin modificaciones ${ }^{11}$ y cuyas disposiciones no resultan del todo acordes a la Carta vigente ${ }^{12}$. Si bien se han formulado diversos requerimientos de inaplicabilidad a su respecto, éstos no han prosperado en definitiva ${ }^{13}$.

Parte del texto del decreto ley ha caído en desuso ${ }^{14}$ o difiere sustancialmente de las reglas procedimentales vigentes ${ }^{15}$. Además, cabe criticar

10 El Decreto Ley $N^{\circ} 2186$ se publicó bajo la vigencia del Acta Constitucional $N^{\circ} 3$ (Decreto Ley
$N^{\circ} 1552$, D.O. 13 septiembre 1976), cuyo texto difiere del contenido de la garantía a la pro-
piedad finalmente consagrado por la Constitución de 1980. La principal diferencia radica en la
posibilidad de pagar parte de le indemnización expropiatoria en un plazo máximo de cinco años,
ampliable a diez para las nacionalizaciones (inciso $4^{\circ}, N^{\circ} 16$ artículo $1^{\circ}$ del Decreto Ley $N^{\circ} 1552$ ).
11 La única modificación que expresamente ha sido introducida al decreto ley corresponde al ar-
tículo único de la Ley $N^{\circ}$ Ley $N^{\circ} 18.932$ (D.O. 10 febrero 1990), relativa a la elaboración del listado
de peritos habilitados para actuar como tasadores en la etapa administrativa del procedimiento.

12 Así, por ejemplo, el artículo 16 del decreto ley contempla el pago de la indemnización sujeta a plazo y bajo un sistema reajustable, en tanto la Carta Fundamental vigente exige el pago de contado. A su vez, el artículo 37 prevé reglas especiales para la expropiación de la pequeña propiedad raíz, talleres artesanales e industrias pequeñas, pero la Constitución finalmente no contempló regímenes expropiatorios diferenciados. Dichas disposiciones carecen de aplicación en la actualidad.

${ }^{13}$ Se han presentado distintos requerimientos de inaplicabilidad en contra de disposiciones del Decreto Ley $N^{\circ} 2816$, aunque referidos a aspectos más bien sustantivos. Por ejemplo, respecto del artículo 12, en cuanto confiere legitimación activa al expropiante para reclamar de la indemnización expropiatoria provisional, sentencias TC Roles $N^{\circ} 4953$ (2019) y No 5270 (2019); en contra del artículo 14, que no prevé reajustabilidad de la indemnización definitiva determinada judicialmente, sentencia TC Rol № 1576 (2010); respecto del inciso $1^{\circ}$ del artículo 20 que, con ocasión del pago de la indemnización o su consignación judicial, radica de pleno derecho en el expropiante el dominio del bien, sentencia TC Rol No 2900 (2017); en contra del inciso final del artículo 20, en tanto exige que conste por escritura pública o sentencia judicial el título que habilita a los arrendatarios, comodatarios y otros terceros para demandar una indemnización por la extinción de sus derechos, sentencia TC Rol №3302 (2017); o respecto del inciso $2^{\circ}$ del artículo 21 que, a falta de acuerdo entre las partes, autoriza al expropiante a tomar posesión material previa consignación judicial de la indemnización provisional, sentencia TC Rol № 1038 (2008). Todas estas inaplicabilidades fueron finalmente desestimadas por el Tribunal Constitucional. Probablemente los únicos requerimientos de inaplicabilidad en virtud de los cuales dicho tribunal ha llegado a pronunciarse sobre aspectos estrictamente procesales del ejercicio expropiatorio apuntan más bien al Código de Procedimiento Civil y la limitación contenida en el inciso $2^{\circ}$ del artículo 768 inciso $2^{\circ}$ para la interposición del recurso de casación formal. Vid. nota $\mathrm{N}^{\circ} 8$.

14 Además de las disposiciones que pugnan con el texto definitivo de la Constitución de 1980, ello ocurre, por ejemplo, con el artículo $7^{\circ}$ en cuanto consagra la notificación del acto expropiatorio por medio de Carabineros de Chile y su inscripción conservatoria preventiva cuando recae sobre bienes sujetos a registro.

15 En el aspecto administrativo, basta con advertir que el procedimiento del decreto ley es anterior a los principios previstos tanto por la Ley No 18.575 (D.O. 05 diciembre 1986), Orgánica Constitucional de Bases Generales de la Administración del Estado, como la ley 19880 (D.O. 29 mayo 2003), sobre bases de los procedimientos administrativos, de manera que no contiene, por ejemplo, el régimen recursivo vigente. En el ámbito judicial, difiere de las modificaciones introducidas al Código de Procedimiento Civil, por ejemplo, en relación con la exención de acompañar documentos a la demanda (Ley No 18.705, D.O. 24 mayo 1988) o la designación de peritos previamente enlistados (letra b, artículo único Ley No 20.192, D.O. 26 junio 2007). Todo lo anterior, sumado a los desafíos que planteó su adaptación a la tramitación electrónica judicial establecida por la Ley No 20.886 (D.O. 18 junio 2016) y la futura transformación digital del Estado prevista en la Ley $N^{\circ} 21.180$ (D.O. 11 noviembre 2019). 
que posee una construcción intrincada, con articulados extensos, que suelen agrupar ideas muy distintas o inconexas entre sí, y que, en ocasiones, pueden parecer contradictorios ${ }^{16}$. Ello propicia la existencia de interpretaciones sustancialmente distintas en torno a algunas de sus disposiciones ${ }^{17}$.

Producto de lo anterior, a nuestro entender, una interpretación armónica de las diversas disposiciones del decreto ley es un ejercicio que no resulta posible realizar satisfactoriamente sin atender a las soluciones construidas por la jurisprudencia de los tribunales y las prácticas sostenidas a lo largo de los años por los distintos operadores jurídicos.

\section{Estructura del procedimiento expropiatorio vigente}

Conforme al decreto ley, la concreción de todo proceso expropiatorio se verifica en dos fases: una administrativa y otra judicial. Dicha regla se rompe únicamente en aquellos casos en que el expropiado se allana a la expropiación y las partes acceden a suscribir un acuerdo ad referendum, opción esta última que parece ser considerablemente menor frente al número de expropiaciones que se judicializan en Chile $^{18}$.

La fase administrativa se inicia con la etapa de estudio (no es indispensable que se dicte una resolución formal para estos efectos), continúa con la determinación de la indemnización provisional por una comisión de peritos, y culmina con la dictación del acto administrativo que ordena la expropiación. Se desarrolla íntegramente al alero del órgano de la Administración del Estado que dicta el acto ablatorio.

Salvo que el expropiante requiera el auxilio de la fuerza pública para forzar el reconocimiento del bien durante la fase preparatoria, la etapa judicial se inicia una vez concluida la administrativa. La judicialización surge del mandato normativo de someter la ejecución del acto expropiatorio a un control jurisdic-

\footnotetext{
16 Por ejemplo, determinar el momento en que opera la incomerciabilidad prevista en los artículos $2^{\circ}, 7^{\circ}$ y $8^{\circ}$ del decreto ley cuando no existe resolución de estudio ni subinscripción conservatoria del acto expropiatorio. Vid. Muñoz Ayamante Víctor Hugo (2014).

17 Así, por ejemplo, para Celis DANzInger existirían dos formas de fijar la indemnización provisional, a saber, mediante una comisión pericial o por sentencia judicial. Los tribunales podrían intervenir tanto en la fijación de la indemnización provisoria, de acuerdo a lo previsto en el artículo 12 del referido decreto ley, como de la indemnización definitiva, según lo previsto en el texto Constitucional y el artículo 39 del decreto ley. Vid. Celis DANZINGER 2019, 923. La opinión generalmente sostenida, en cambio, plantea que la intervención judicial opera únicamente para la fijación definitiva de la indemnización, de modo que la acción prevista en el artículo 12 del decreto ley sería la misma que aquella dispuesta en la parte final del inciso $3^{\circ}$ del N ${ }^{\circ} 24$ del artículo 19 de la Constitución. Vid. Rios Álvarez 1978, 82; Morales Gana 1999, 23; Bermúdez Soto 2014, 603.

18 En el caso del Ministerio de Obras Públicas, durante el año 2016, del total de 1161 expropiaciones tramitadas, 309 se concretaron a través de convenio y 852 por vía judicial; durante 2017, hubo 1523 expropiaciones tramitadas, 458 por convenio y 1065 vía judicial; y, durante 2018, 1452 expropiaciones tramitadas, 439 por convenio y 1013 judicialmente. Lo anterior, nos permite advertir que se celebró convenio administrativo solo en el $30 \%$ de las expropiaciones sustanciadas por dicho órgano durante esos años. Datos estadísticos obtenidos por medio de solicitud de acceso a la información pública de 11 de septiembre de 2019, dirigida a la Fiscalía del Ministerio de Obras Públicas.
} 
cional obligatorio; a falta de acuerdo, la Administración requiere de autorización judicial, lo que constituye una excepción a su facultad de autotutela ${ }^{19}$.

A diferencia de la etapa administrativa, la judicial no considera la sustanciación de un procedimiento único, pues la norma prevé tramitaciones diversas, según la pretensión sometida a la decisión del tribunal. Entonces, tenemos que la judicialización de la expropiación puede albergar una diversidad de causas que, en principio, se tramitan de forma independiente ${ }^{20}$.

Existen procedimientos contenciosos ${ }^{21}$, dispuestos para sustanciar cuatro grandes grupos de acciones: 1) las que controvierten la validez ${ }^{22}$, vigen$\mathrm{cia}^{23}$ o extensión ${ }^{24}$ del acto expropiatorio; 2) las que refieren exclusivamente al quantum de los daños patrimoniales sufridos ${ }^{25}$; 3) una acción conservati$v^{26}$; y 4) las acciones de cobro que acreedores y titulares de derechos reales sobre el bien expropiado pueden hacer valer respecto de la indemnización ${ }^{27}$.

\footnotetext{
19 Vid. Bermúdez Soto 2014, 156; Valdivia 2018, 205.

20 La Corte Suprema ha sostenido: "[...] la disposición que ordena el depósito del monto provisional de la indemnización en la cuenta corriente del tribunal competente no tiene otro alcance que ése y el de radicar la competencia del tribunal pertinente, conforme al artículo 39 del D.L. $\mathrm{N}^{\circ} 2.186$ [...] las reclamaciones constituyen procedimientos totalmente independientes y separados. [...] refuerza la autonomía de los distintos cuadernos y gestiones que pueden darse con motivo de una expropiación, la circunstancia de que en algunos de ellos las partes pueden tener, indistintamente y aún coetáneamente, el carácter de actor y de sujeto pasivo;". La misma sentencia agrega: "[...] Que, precisado lo anterior, la conclusión es inevitable: lo que ocurra en un cuaderno, que se tramita separadamente de los otros, que constituyen procedimientos independientes, carece de trascendencia respecto de lo que se resuelva en los demás, en relación con la materia en discusión;". Vid Sucesión Benjamín Mucientes Morales con Fisco de Chile (2003), considerandos $7^{\circ}$ y $8^{\circ}$; en el mismo sentido, vid. Velásquez Carreño con Fisco de Chile (2015), considerando $3^{\circ}$.

21 Cabe advertir que estos procedimientos están sujetos a reglas radicalmente diversas, a la vez que presentan diversos grados de desarrollo en el decreto ley. Ya en 1978 Rios Álvarez criticó la poca atención que el legislador dedicó a una cuestión principal y de la esencia de toda expropiación, como es la determinación de la indemnización definitiva; en contraposición a los largos pasajes que la norma destinó a regular una cuestión totalmente accesoria y eventual, como es la comparecencia de terceros para repartirse la indemnización. Cfr. Ríos Álvarez 1978, 113.

22 Reclamo de legalidad (nulidad) del acto expropiatorio, previsto en el literal a), artículo $9^{\circ}$ del Decreto Ley $\mathrm{N}^{\circ} 2.186$, en relación con el inciso $3^{\circ}, \mathrm{N}^{\circ} 24$, del artículo 19 de la Constitución. También agregamos aquí el reclamo de legalidad en la forma de pago de la indemnización, contemplado en el literal d), artículo $9^{\circ}$ del Decreto Ley $N^{\circ} 2.186$, aunque este último no persigue el cese del acto expropiatorio, sino solo su corrección.

23 Acción de caducidad del acto expropiatorio, artículos 21, inciso $3^{\circ}, 33$ y 34 del Decreto Ley $\mathrm{N}^{\circ} 2.186$.

24 Acciones de ampliación del acto expropiatorio, letras b) y c) del artículo $9^{\circ}$ del Decreto Ley $\mathrm{N}^{\circ} 2.186$.

25 Acción de reclamo del monto de la indemnización expropiatoria (artículo 12), de indemnización por la extinción colateral de derechos que no pueden hacerse valer respecto de la indemnización expropiatoria (artículo 20, inciso final) y de indemnización por expropiación desistida o que ha caducado (artículo 35) todos del Decreto Ley $N^{\circ} 2.186$.

26 La acción de recolección de frutos pendientes, artículo 21 del Decreto Ley $N^{\circ} 2186$.

27 Acción de cobro de terceros sobre la indemnización expropiatoria (verificación de créditos), prevista en el inciso $2^{\circ}$ del artículo 20 del Decreto Ley $N^{\circ} 2.186$.
} 
En otro orden, la expropiación requiere de dos trámites judiciales indispensables: la consignación de la indemnización provisional y la toma de posesión material. A los anteriores se agrega la inscripción conservatoria, en el caso que el bien expropiado se encuentre sujeto a un sistema registral, y el pago de la indemnización al expropiado ${ }^{28}$. Todos los anteriores se agrupan bajo un mismo procedimiento 29 .

Ahora, estos procedimientos se radican ante un mismo tribunal, en virtud de la regla especial de prevención del artículo 39 del Decreto Ley $N^{\circ} 2186$, conforme a la cual, el juez que conoce de la primera actuación vinculada a una determinada expropiación ejerce una competencia atractiva respecto del resto de gestiones que se inicien con ocasión de la misma. Ello, en todo caso, no implica una acumulación de autos ${ }^{30}$.

Así, pese a que su tramitación se sujeta a reglas diversas y se desarrolla de manera independiente, la circunstancia de que todos los procedimientos queden sujetos a un mismo juez propicia una cierta comunicabilidad entre ellos; siguen tramitaciones paralelas, pero que se hallan íntimamente conectadas ${ }^{31}$.

En la regularidad de los casos, el procedimiento de consignación y toma de posesión material constituye el núcleo central de la actividad judicial que concierne a la expropiación, en torno al cual se desarrolla el resto de los trámites y reclamaciones judiciales. Más aún, en muchos otros, se trata de la única intervención judicial que se promueve a propósito del proceso expropiatorio.

La naturaleza de dicho procedimiento ha sido reiteradamente definida como voluntaria ${ }^{32}$, incluso a nivel jurisprudencial ${ }^{33}$. Pese a ello, la ejecución

\footnotetext{
${ }^{28}$ El Tribunal Constitucional ha sostenido que: "Reiterando lo ya aseverado, el pago de la indemnización es un requisito de la expropiación, pero no lo es cobrar y percibir esa compensación, pues hacerlo es un acto voluntario del expropiado y no un elemento de la esencia de esa institución jurídica". Vid. Sentencia TC Rol №552 (2008), considerando 40. En el mismo sentido vid. sentencias TC Roles No 1038 (2008), considerando $14^{\circ}$ y $N^{\circ} 2900$ (2017), considerando 34․

29 Morales Gana 1999, 7; Ponce Correa 2011, 209.

30 Cfr. Peña Mardones 2001, 72.

${ }^{31}$ Así por ejemplo, el plazo de caducidad de la acción para reclamar el monto de la indemnización provisional se cuenta a partir de la toma de posesión material; la caducidad de la expropiación surge una vez que vence el plazo de que dispone el expropiante para instar por la toma de posesión material; la verificación de créditos en el procedimiento de liquidación de la indemnización se formula a partir de la consignación; la solicitud de recolección de frutos se promueve en forma previa a la toma de posesión material, por mencionar algunos ejemplos.

32 Vid. Rios Álvarez 1978, 76; Morales Gana 1999, 7; y Ponce Correa 2011, 209.

33 La Corte Suprema ha señalado: "[...] Que, en tales condiciones, han perdido vigencia en esta materia las normas sobre expropiación del Código de Procedimiento Civil, y la única gestión voluntaria que se contempla en dicho nuevo conjunto especial de asuntos es la consignación de la indemnización provisional a la orden del juzgado de letras competente; tribunal que, por economía procesal, se hace cargo posteriormente del proceso de reclamo, si éste se concreta, en un procedimiento que ya adquiere carácter contencioso". Vid. Inversiones Piedra Roja Limitada con Fisco de Chile (2005), considerando $17^{\circ}$. En el mismo sentido: "[...] la gestión de pago por consignación del monto provisional por causa de expropiación es un procedimiento voluntario, es decir, no contencioso, y como tal, no se dirige con forma de juicio en contra del expropiado, aun cuando éste o terceros afectados por el acto de autoridad, conforme a los derechos que les
} 
de una expropiación envuelve, muchas veces, una contienda ínsita evidente, que deriva de la privación coactiva de la propiedad; tanto así, que el inciso final del artículo 21 del decreto ley expresamente autoriza el auxilio de la fuerza pública por la oposición material, sin que por ello adquiera el carácter de juicio.

En este sentido, ¿por qué definir como no contencioso un procedimiento que envuelve una colisión de derechos e intereses entre dos sujetos? Intentaremos a continuación dilucidar en qué medida ambas definiciones pueden ser compatibles.

\section{Delimitación del concepto de procedimiento no contencioso}

De lo previsto en los artículos $2^{\circ}$ del Código Orgánico de Tribunales y $1^{\circ} \mathrm{del}$ Código de Procedimiento Civil, se desprende la competencia de los tribunales para conocer de los procedimientos judiciales no contenciosos, cuando una "ley expresa requiera su intervención". Empero, dichas normas no fijan un criterio diferenciador de esta clase de procedimientos.

Tal distinción surge del artículo 817 del Código de Procedimiento Civil, el cual precisa que "[s]on actos judiciales no contenciosos aquellos que según la ley requieren la intervención del juez y en que no se promueve contienda alguna entre partes". A partir de esta norma, se suele concluir que serían dos los elementos que caracterizan a esta clase de gestiones.

En primer término, la existencia de una ley expresa que así lo disponga. La creación de procedimientos judiciales no contenciosos es, por tanto, materia de reserva legal ${ }^{34}$. Por esta razón se ha llegado a sostener que, a diferencia de los asuntos contenciosos, en estos casos la intervención judicial solo resulta válida en la medida que el legislador la ha previsto expresamente y no más allá de tales asuntos ${ }^{35}$.

En segundo lugar, se requiere que esta clase de procedimientos no encierren una contienda entre partes, entendida como la existencia de un

\footnotetext{
franquea la Ley Orgánica de Procedimiento de Expropiaciones, puedan ejercer una o varias de las acciones allí determinadas [...]". Alzua Elizalde con Fisco de Chile (2010), considerando 14.

${ }_{34}$ Cfr. CaSARINO Viterbo 1995, 61. Más que una diferencia en torno a la legalidad-pues en ambos casos la intervención del juez se sustenta en una habilitación legal previa-, diremos que se trata de una cuestión de tipicidad o especificidad normativa. La competencia judicial en materia contenciosa se halla definida en términos amplios y genéricos, de ahí la posibilidad de llegar a ejercer acciones de declaración de mera certeza; mientras que la jurisdicción voluntaria recae sobre gestiones específicas.

35 " [...] El hecho de que un contrato no sea una verdadera ley determina que no pueda ser fuente de competencia para tales actos. [...] En este sentido, no pueden las partes mediante contrato atribuir competencia absoluta a los tribunales para practicar una gestión que no se encuentra prevista en la legislación. No basta, por tanto, que el recurrente invoque el contrato como fuente de competencia para la gestión voluntaria de notificación de desahucio de contrato social. Es necesario que una ley atribuya dicha competencia a los tribunales." Landerretche Diaz y Otros con Luis Zegpi Jimenez (2015), considerando $7^{\circ}$.
} 
conflicto por oposición de un legítimo contradictor ${ }^{36}$. Este parece ser un elemento esencial en esta clase de procedimientos y así se destaca comúnmen$t^{37}$. De esta forma, la aparición posterior de un opositor conlleva la transformación del asunto en contencioso, según lo prevé el artículo 823 del código.

Para la mayoría de los autores, la idea de contienda que toca ser dirimida corresponde a un elemento distintivo de la función jurisdiccional, cuestión que los lleva a concluir que los procedimientos voluntarios no envuelven un ejercicio de este carácter ${ }^{38}$ y, en muchos casos, a calificarlos como una función administrativa ejercida por tribunales ${ }^{39}$, incluso reemplazable por gestiones notariales ${ }^{40}$.

No obstante, en nuestro parecer, no cabe asimilar la intervención judicial no contenciosa al ejercicio administrativo o notarial. Si bien los tres representan vías aptas para la satisfacción de necesidades sociales de certeza jurídica, a la vez que optar por una u otra responde a una decisión normativa que se evidencia mutable en el tiempo ${ }^{41}$, ello no ofrece motivo suficiente para equipararlas jurídicamente ${ }^{42}$, pues tal decisión resulta significativa para sus destinatarios.

Creemos que la intervención judicial voluntaria posee una naturaleza jurisdiccional ${ }^{43}$. Negarle este carácter, en oposición a la resolución de asuntos

36 Vid. COUture 2007, 41.

37 Vid. Orellana Torres 2008, 92; Lillo Hunzinker 2012, 38; Correa Selamé 2014, 46.

38 Vid. Chiovenda 1977 [1923], 393; Calamandrel 1996 [1944], 191; Quezada Meléndez 1984, 198; Couture 2007, 41; Pereira Anabalón 1993, 151; Núñez Ojeda y Pérez Ragone 2013, 59; Correa SelaMÉ 2014, 45, entre otros. Para una revisión de las diversas posturas en torno a la discusión acerca de la naturaleza de los actos de jurisdiccional voluntaria, vid. González Poveda 2008, 53-67.

39 Esta es la postura dominante al interior de la doctrina procesalista clásica. Vid. SATTA 1971 [1968], 298; Pereira Anabalón 1993, 151.

40 La negación del carácter jurisdiccional de la gestión contenciosa ha servido como fundamento para transformar determinadas actuaciones judiciales en notariales. Así puede verse en el caso del acta de notoriedad prevista en el sistema español por la ley 10/1992 (30 abril 1992), para obtener la declaración de que determinadas personas son herederos únicos de una sucesión abintestato. Vid Fernández-Treguerres García 1996, 3882- 3907. En el mismo sentido, concluye Gerona Peña que la función notarial comparte los mismos principios que las gestiones judiciales no contenciosas y sostiene que la asignación de actos de jurisdicción, ya sea a los jueces u otros funcionarios, es un asunto netamente coyuntural. Cfr. Gerona PeÑa 1996, 3909-3960.

${ }^{41}$ Por ejemplo, en Chile, la Ley No 19.903 (D.O. 10 octubre 2003) entregó al Servicio de Registro Civil e Identificación la tramitación de las posesiones efectivas de herencia intestadas, lo que antes era competencia de los juzgados de letras en lo civil. En relación a la expropiación, antiguamente el procedimiento contemplado en el artículo 919 del Código de Procedimiento Civil, así como el Reglamento de Expropiaciones para Obras Públicas aprobado por Decreto № 2.651 del Ministerio de Fomento (D.O. 11 octubre 1934), exigían para su perfeccionamiento la suscripción de una escritura pública en el caso de los inmuebles, en tanto hoy, el perfeccionamiento, a falta de acuerdo, es netamente por vía judicial.

${ }^{42}$ En este sentido, anota SATTA que los intentos de negar el carácter jurisdiccional de los actos no contenciosos, asimilándolos a la función administrativa y notarial, obedece esencialmente a la negación del carácter público de esta función, bajo una visión eminentemente privatista de tales asuntos. Cfr. SATTA 1971 [1968], 298.

${ }^{43}$ Diversos autores se han pronunciado reafirmando el carácter jurisdiccional de esta función judicial. Para DE PINA la jurisdicción voluntaria se apoya en la necesidad de tutelar o garantizar una determinada situación jurídica relevante, vid. De Pina 1936, 102. Para Carnelutti dicho carácter 
contenciosos pasa especialmente por su construcción a partir de una errónea interpretación del elemento conflictual como criterio diferenciador ${ }^{44}$.

Y es que, si bien éste parece fluir de la definición legal, cabe advertir que la existencia de una contienda jurídica es una cuestión de naturaleza eminentemente casuística (fáctica), verificada ex post; en tanto la definición procedimental, un asunto normativo, que acontece ex ante. La existencia de un conflicto se presenta con posterioridad a la definición procedimental, de modo que no puede ser un elemento estimado en términos materiales, sino normativos.

Existirán procedimientos definidos como contenciosos que, pese a ello, no encierren una disputa efectiva entre las partes, del mismo modo que habrá gestiones definidas a priori como voluntarias y que alberguen un conflicto entre diversos sujetos. Entonces, el carácter voluntario deviene de un diseño legislativo, antes que de una controversia concreta entre sujetos.

A nuestro entender, la naturaleza voluntaria radica en que el procedimiento no se dirija formalmente en contra de "otro", lo que no excluye que -en la práctica- existan sujetos a quienes afecte o interese la decisión y puedan estar en abierto conflicto con lo peticionado. Se trata de calificar su intervención como algo no esencial, por tanto, prescindible: ya desde el inicio, como durante su sustanciación ${ }^{45}$.

El elemento determinante en la definición contenida en el artículo 817 no es, entonces, el término "contienda" sino la locución "entre partes"; esto es, la circunstancia de existir sujetos que ocupan posiciones jurídicas predefinidas por el legislador y sin cuyo emplazamiento concreto, no se admite el inicio del procedimiento o su prosecución.

\footnotetext{
se sustenta en el propósito preventivo que persiguen las gestiones no contenciosas, pues con ellas se busca regular con justicia y de manera cierta, determinadas situaciones jurídicas en que el peligro de injusticia o la falta de certeza resulta grave. Vid. CARNeLuTTI 1973a [1956], 44-53. Su conformación jurídica no obedece a la existencia de una pretensión dirigida en contra de una parte determinada, pero supone la tutela especial de una parcela importante del ordenamiento jurídico, ya se trate de derechos disponibles como indisponibles. Cfr. Fernández de Buján 2001, 185. En el ámbito nacional, participa de esta postura CASARINO VITERBO, para quien la intervención judicial no contenciosa corresponde un ejercicio jurisdiccional de carácter sui generis. Vid. CASARINO VITERBO 1995, 62.

44 Anota Hoyos HenReCHSON que la definición legal resulta defectuosa en estos términos pues, de aplicarse el criterio de ausencia de conflicto, tendría que calificarse el juicio en rebeldía como una gestión no contenciosa. Cfr. Hoyos HenReCHSON 2001, 61.

45 En la jurisdicción no contenciosa no existe pretensión frente a una persona concreta, pero sí una tutela conferida por el ordenamiento jurídico, tanto respecto de derechos subjetivos, como de situaciones o intereses individuales, especialmente cuando la intervención judicial posee un carácter constitutivo o preceptivo. Cfr. FernándeZ de Buján 2001, 102.
} 


\section{Algunos elementos diferenciadores de un procedimiento no conten- cioso}

Asentado lo anterior, diremos que la jurisdicción voluntaria es, ante todo, una técnica legislativa de simplificación procedimental, que agrupa una serie de gestiones diversas, con el fin de someter a un control jurisdiccional, más o menos intenso, determinadas actuaciones de relevancia jurídica práctica, sin exigir para ello un emplazamiento legal concreto.

Existe reserva legal ${ }^{46}$, de ahí que hablemos de técnica legislativa. Ahora, la definición normativa en torno a la fijación de un determinado procedimiento encierra, entonces, dos decisiones relevantes: 1.- el sometimiento de esta materia a la resolución de un tribunal y, con ello, a un control jurisdiccional; a diferencia de lo que ocurre cuando se confía su conocimiento a la función administrativa o notarial ${ }^{47}$; y 2.- la de sujetarlo a un procedimiento no contencioso.

La primera de estas decisiones parte de reconocer que el sometimiento de un asunto a la resolución de un órgano jurisdiccional ofrece mayores garantías a los individuos ${ }^{48}$. La imparcialidad del juzgador, la invariabilidad de la decisión firme, la facultad de ejecutar la resolución coactivamente y la posibilidad de requerir la inaplicabilidad de un precepto legal decisorio, parecen ser algunos de los elementos distintivos ${ }^{49}$.

La segunda decisión refiere precisamente a la determinación ex ante de que la intervención de los eventuales afectados o interesados no va a ser elevada al carácter de esencial, sino eventual ${ }^{50}$. El inicio y sustanciación del

\footnotetext{
46 Vid. notas $N^{\circ} 34$ y 35.

47 Anota Fernández de BuJÁn que, a diferencia de la jurisdicción voluntaria, el procedimiento administrativo se caracteriza, en la mayoría de los casos, por la defensa de intereses generales y no individuales, así como también, por la posibilidad de silencio como respuesta. Cfr. FERNÁNDEZ DE Buján 2001, 105. Para CAMACHo Cepeda la decisión administrativa, en oposición a la jurisdiccional, se distingue especialmente por la posibilidad de iniciar el procedimiento de oficio, las amplias facultades del resolutor para recopilar antecedentes probatorios, la posibilidad del órgano de requerir de oficio la intervención de otros sujetos en el procedimiento y por el hecho de que, reclamada la decisión, el órgano administrativo puede hacerse parte de la discusión ante el tribunal Ilamado a resolverla. Cfr. CAMACHO CePEDA 2019, 243.

48 La idea de otorgar plena competencia al órgano jurisdiccional, como garantía de control de la actividad administrativa ablatoria, estuvo presente al interior de la Comisión de Ortúzar y quedó asentada desde los inicios de la discusión. Así, por ejemplo, se consigna que "El señor RODRíGUEZ (Miembro de la Subcomisión de Derecho de Propiedad), da a conocer que la idea que primó en la Subcomisión podría llamarse de concentración, o sea, de que el acto expropiatorio contiene, por sí, todos los elementos [...] con los cuales puede haber controversia o conformidad. Agrega que respecto de este acto expropiatorio se permite también [...] al expropiado, dentro de cierto plazo, [...] objetar todos y cada uno de los elementos indicados en el acto expropiatorio, yendo, por lo tanto, todo esto a la justicia ordinaria y en forma privada". Vid. Actas oficiales de la Comisión de Estudio de la Nueva Constitución, sesión N $164^{\text {a }}$ de 06 de noviembre de 1975.

49 En este mismo sentido vid. CAMACHo Cepeda 2019, 243.

50 Creemos que ello puede obedecer a diversos factores, tenidos en cuenta por el legislador al momento de definir cada gestión voluntaria en particular. La presunción de que el índice de conflictividad de ciertas decisiones es marginal, la consideración de que los bienes jurídicos afecta-
} 
procedimiento no se condicionan a la identificación previa de un sujeto en contra del cual se dirige y, por tanto, conlleva eximir al requirente de definir e individualizar a una "contraparte" ${ }^{51}$.

En estos procedimientos no hay un emplazamiento ${ }^{52}$, entendido este último como el traslado que se confiere a un opositor, conminándolo a defender sus derechos e intereses en el procedimiento ${ }^{53}$. Así, no resulta necesario procurar que el pedimento se notifique específicamente a alguien.

No tiene aplicación la regla prevista en el artículo 40 del Código de Procedimiento Civil ni, por lo general, se prevén otras fórmulas de notificación cierta. Usualmente se emplean mecanismos que confieren una publicidad general e inespecífica, como las publicaciones. Solo se busca ofrecer una posibilidad de conocimiento a los eventuales afectados e interesados.

La simplificación procedimental, en tanto, se advierte de la exención de trámites que se consideran esenciales al interior de la jurisdicción contenciosa, como el término probatorio. En general, las gestiones no contenciosas poseen un carácter no formalizado ${ }^{54}$. No aplica en estos casos el abandono

\footnotetext{
dos son disponibles para el solicitante, el carácter precario de la decisión, la existencia de otras vías de impugnación o, incluso, la intención decidida de que un asunto sea resuelto con mayor celeridad, puede ser algunos de estos motivos. En este sentido, advierte Véscovı que esta elección incluso puede obedecer a fines de control estatal y evidencia que cuando el Estado adquiere un rol de mayor intervención en el ámbito social, generalmente se produce un crecimiento de los casos de jurisdicción voluntaria, pues con ello el control del Estado alcanza campos más vastos; por ejemplo, establecer que múltiples cambios de las relaciones o estados jurídicos de las personas no puedan verificarse sino con la intervención del órgano jurisdiccional. Cfr. Véscovı 2006, 108. En el caso de la gestión de consignación y toma de posesión material por expropiación fue determinante la preocupación de la Comisión Ortúzar y la Subcomisión de Derecho de Propiedad que la obligación de pago y eventual discusión del monto de la indemnización no llegara a entrabar el ejercicio de la potestad expropiatoria y, con ello, el fin público que ésta persigue. Vid. Actas oficiales de la Comisión de Estudio de la Nueva Constitución, sesión N ${ }^{a} 250^{\mathrm{a}}$ de 5 de octubre de 1976.

51 De esta manera, distinguimos dos modelos procesales: a) el de los juicios ordinarios de cognición, que comprende tanto aquellos supuestos en que existe una efectiva controversia entre partes, como aquellos otros en que, habiéndose planteado un contradictorio, este último se resuelve sin allanamiento, debate ni controversia; y b) los juicios de jurisdicción voluntaria, que comprende aquellos supuestos en los que, sin existir una pretensión en contra de alguien, ni controversia de especial relevancia, el juez actúa por un imperativo normativo de carácter legal, en la defensa de intereses públicos o sociales, o con carácter constitutivo, autorizando y controlando la legalidad de dicha actuación. Cfr. FernándeZ de BuJÁn 2001, 104.

52 El emplazamiento se considera un presupuesto esencial de la relación procesal en los procedimientos contenciosos, a partir el cual suceden dos consecuencias relevantes: 1.- la litispendencia; y 2.- el surgimiento para el afectado de la posibilidad de ejercer una defensa judicial. Cfr. Romero Seguel 2015, 121. Las gestiones voluntarias, en cambio, carecen de sustento bilateral y no materializan una relación procesal perfecta, pues los derechos que surgen en su virtud se amparan en el ejercicio unilateral del solicitante, sin un sujeto pasivo determinado; de ahí la negativa de algunos a reconocer esta clase de intervención judicial como un ejercicio jurisdiccional. 53 Cfr. Cortez Matcovich 2013, 122.

54 Los juicios de jurisdicción voluntaria se caracterizan por una mayor agilidad y menor formalidad, amplios poderes del juez y economía procedimental. Se limitan algunas garantías en
} 
del procedimiento 55 y, aunque existen importantes excepciones, sus actuaciones no se hallan sometidas al cumplimiento de plazos perentorios ni a la preclusión.

La diversidad deviene de la existencia de gran cantidad de estos procedimientos, regulados tanto en el Código de Procedimiento Civil como en normas especiales ${ }^{56}$. La doctrina nacional ha formulado distintas clasificaciones que, con matices, permiten agruparlas en cuatro a cinco clases diversas ${ }^{57}$, aunque se suele cuestionar la completitud de tales divisiones ${ }^{58}$.

En otro orden de ideas, como no hay partes, tampoco existe necesidad de concebir la prueba bajo una óptica bilateral ${ }^{59}$. No se prevén mecanismos para impugnarla, tampoco resulta necesario sujetar su rendición a una ritualidad específica o enmarcarla dentro de un período especial ${ }^{60}$. Más aún, no parece posible exigir al juez un estándar de convicción similar al de un proceso contradictorio, pues evidentemente la aportación y calidad de la prueba será inferior.

Esta circunstancia se contiene expresamente en el artículo 818 del Código de Procedimiento Civil, conforme a la cual los tribunales no quedan sometidos en estas gestiones a las "solemnidades ordinarias de las pruebas judiciales", de modo que los hechos pueden acreditarse mediante "prueba de cualquiera especie, rendida sin notificación ni intervención de contradictor y sin previo señalamiento de término probatorio"61.

comparación a los procesos contradictorios, pero preservando aquellas de carácter esencial. Cfr. FERNÁNDEZ de BuJÁn 2001, 105.

55 Vid. Correa Selamé 2016, 44.

56 El listado de códigos para el ingreso de demandas del Poder Judicial considera al menos 38 gestiones no contenciosas distintas.

57 Vid. Quezada Meléndez 1984, 216; Casarino Viterbo 1995, 63; Lillo Hunzinker 2012, 42.

58 Vid. Pereira Anabalón 1993, 148.

59 En este sentido, sostiene CARNELUTTI que, contrario a la bilateralidad característica del proceso contencioso, se advierte en el voluntario una inmanente unilateralidad; cuestión esta última que no excluye la existencia de un conflicto de intereses en relación al fondo del negocio, sino que se debe a la circunstancia de que, a diferencia de la litis, dicho conflicto no está elevado a un primer plano. Cfr. CARnelutTI 1973b [ 1956], 263.

60 Se sostiene que en un procedimiento contencioso se identifican al menos seis etapas de la actividad probatoria: 1 . ofrecimiento; 2. petitorio de prueba; 3. diligenciamiento; 4. impugnación; 5. observaciones a la prueba; y 6. apreciación de la prueba. Vid. Figueroa YÁAAr y Morgado SAN MARTín 2013, 140. De entre todos ellos, la impugnación se evidencia como la gran ausente en el caso de la jurisdicción no contenciosa.

61 La Corte Suprema ha señalado: "[...] puede razonablemente predicarse que los asuntos de jurisdicción voluntaria no están sujetos al derecho probatorio, como quiera que éste se levanta sobre la base esencial de una controversia sustentada en presupuestos de hecho cuya comprobación resulta indispensable para el logro final de la convicción de quienes están llamados a una adjudicación de la que no puede estar ausente su circunstancialidad fáctica; [...] Al ser el ordenamiento comunitario el que ha creído conveniente la intervención judicial en cierto tipo de materias, no obstante no existir una contienda en la que se anide una pretensión de marca privada -en contraposición a la pública- se deja en manos de la judicatura una performance indagatoria e informativa de corte inquisitivo, conducente a una resolución que, para no ser arbitraria, re- 
Ahora bien, esta circunstancia no equivale a afirmar que se trata de una mera constatación de hechos por parte del juez. La intervención de este último corresponde, en todo caso, a un control judicial, de modo que dispone de facultades para ponderar la suficiencia, legalidad y valor de los elementos de prueba impetrados ${ }^{62}$, así como para exigir que se le proporcionen mayores antecedentes de los aportados voluntariamente por el peticionario.

Por último, una calidad discutida en torno a esta clase de procedimientos es el efecto de cosa juzgada. Mientras existen quienes niegan abiertamente la inmutabilidad de las sentencias dictadas en la jurisdicción voluntaria ${ }^{63}$, hay quienes reconocen que, en algunos procedimientos o bajo determinadas condiciones, éstas adquieren el carácter de inamovible ${ }^{64}$, opinión a la que adherimos y estimamos aplicable al caso de la expropiación ${ }^{65}$.

\section{IV. ¿Por qué considerar no contencioso el procedimiento de consigna- ción y toma de posesión material?}

A primera vista, la definición legal de jurisdicción voluntaria y la visión clásica de este instituto parecen no permitir calificar bajo este rubro al procedimiento de consignación y toma de posesión material de expropiación, de momento que éste encierra una evidente relación entre dos o más sujetos.

$Y$ es que, en este caso, el propio decreto ley ha identificado -al menosdos partes en presumible contraposición de intereses debido a la privación coactiva de la propiedad: expropiante y expropiado. Al mismo tiempo, ha dispuesto la práctica de diligencias de notificación respecto de este último y,

quiere ser evacuada al amparo del menormente exigente padrón del 'conocimiento de causa'". Solicitante: Banco Santander Chile (2013), considerandos $3^{\circ}$ y $4^{\circ}$.

62 " [...] Que para dar estricto cumplimiento a lo exigido por el Constituyente y el legislador, los jueces deben razonar jurídicamente sobre los presupuestos de la acción ejercida y ponderar toda la prueba rendida precisando en base a cuál o cuáles probanzas tienen por establecidos los hechos de la causa. [...] Que, al efecto, el artículo 819 del Código de Procedimiento Civil dispone que en estos asuntos los tribunales apreciarán prudencialmente el mérito de las justificaciones y pruebas de cualquier clase que se produzcan y, por su parte, el artículo 826 del mismo compendio ordena que las sentencias definitivas en estos negocios cuando deba procederse con conocimiento de causa deben expresar las razones que motivan la resolución. [...]" Solicitante llustre Municipalidad de Estación Central (2014), considerandos $7^{\circ}$ y $10^{\circ}$.

63 Vid. Chiovenda 1977 [1923], 397; Pereira Anabalón 1993, 150; Couture 2007, 43; Orellana ToRres 2008, 92; Romero Seguel 2017, 126; y Correa Selamé 2014, 47, entre otros.

64 Vid Quezada Meléndez 1984, 219; Casarino Viterbo 1995, 61; Fernández de Buján 2001, 135; así como también, Núñez OJeda y Pérez Ragone 2013, 61.

65 Así, la Corte Suprema ha sostenido: "[...] cabe señalar que de los hechos que se dieron por asentados en la causa, consignados precedentemente, aparece que el supuesto propietario del inmueble expropiado, a la fecha del acto administrativo, era la denominada sucesión Pardo Legrand, a cuyo nombre aparece el decreto respectivo y su publicación, lo que se corresponde con el tenor del certificado de avalúo fiscal del rol No551 9, esto es, el terreno expropiado. [...] no existe dominio alguno que disputar sobre el inmueble expropiado luego de más de 10 años desde la toma de posesión material de éste, resultando el acto expropiatorio plenamente oponible a la parte demandante". José Ugalde Vásquez con Servicio de Vivienda y Urbanización de la Región del Bío Bío (2016), considerandos $14^{\circ}$ y $15^{\circ}$. 
más aún, prevé abiertamente su eventual negativa a facilitar la realización de actos materiales respecto del bien expropiado.

A partir de la consignación el expropiado pierde el dominio del bien 66 $y$, en virtud de la toma de posesión material, su tenencia y disfrute ${ }^{67}$. Se trata así de actuaciones altamente conflictivas y no son extraños los casos en que se intenta, por ejemplo, discutir la suficiencia de la consignación, el título para percibirla o, sobre todo, impedir el desposeimiento, de ahí que la norma permita obtener el auxilio de la fuerza pública para llevarlo a cabo ${ }^{68}$.

Ínsita en todo proceso de expropiación existe, entonces, una alta probabilidad de contienda, además de una identificación de sujetos cuyos intereses o derechos aparecen en colisión. El texto del Decreto Ley No2186 no explicita la naturaleza de la gestión de consignación y toma de posesión material ¿qué lleva a la jurisprudencia y doctrina a considerarla como no contenciosa? A nuestro entender, la ausencia de un emplazamiento concreto del afectado.

Si bien desde un inicio el proceso expropiatorio reconoce la existencia de un expropiado, no pesa sobre la Administración la obligación de identificarlo ni requerirlo de manera efectiva ${ }^{69}$. El decreto ley solo exige señalar "el nombre del o de los propietarios o de los que aparezcan como tales en el rol de avalúos o los datos que faciliten su determinación", de modo que, finalmente, la indicación del afectado contenida en el acto expropiatorio es referencial ${ }^{70}$.

De esta forma, a no ser que el ente expropiante llegue a acuerdo con el propietario del bien y pague directamente a este último sin intervención de un tribunal, cuando la expropiación se judicializa, la determinación de la identidad

\footnotetext{
66 Artículo 20 del Decreto Ley $N^{\circ} 2.186$.

67 Señala Cea Egaña que la toma de posesión material, a la que prefiere referirse como desposeimiento, corresponde a un trámite sustantivo que debe ser entendido en su sentido natural y obvio, como la privación del bien cuya posesión aún detenta el expropiado. Cfr. CEA Egaña 2012, 590.

68 Inciso final del artículo 21 del Decreto Ley $N^{\circ} 2.186$.

69 La discusión al interior de la Comisión Ortúzar da cuenta de que el proyecto de ley de procedimiento de expropiaciones no exigiría la precisa individualización del propietario del bien. A propósito de las observaciones presentadas por los Ministerios, consta haberse acordado que "[...] el proyecto no pretende que siempre se indique precisamente el nombre del propietario, sino que al menos se indiquen los datos que faciliten su individualización". Por esta razón se aprobó finalmente agregar la frase "el nombre del o de los propietarios o de los que aparezcan como tales en el Rol de Avalúos". Vid. Actas oficiales de la Comisión de Estudio de la Nueva Constitución, sesión $N^{\circ} 262^{a}$ de 25 de noviembre de 1976.

70 La Corte Suprema sostuvo: "[...] la Ley de Expropiaciones permite que se lleve a cabo el proceso expropiatorio aún sin tener claridad sobre la identidad del expropiado, lo que se manifiesta por ejemplo, en que dentro de las menciones del acto expropiatorio no resulta necesario indicar el nombre del propietario sino que basta con señalar el nombre de los que aparezcan como tales en el rol de avalúos o, incluso, solo incluir los datos que faciliten su determinación, resguardando eso sí que el dinero que le correspondería se encuentre a su disposición consignándolo en el tribunal respectivo [...]". Bedoya Herrera Jorge Eduardo Gonzalo con Serviu Metropolitano (2013), considerando $19^{\circ}$. En el mismo sentido vid. José Ugalde Vásquez con Servicio de Vivienda y Urbanización de la Región del Bío Bío (2016), considerando $11^{\circ}$.
} 
del expropiado recae fundamentalmente en el juez ${ }^{71}$, quien deberá proceder a la revisión de los títulos antes de pagar la indemnización consignada ${ }^{72}$.

Coincidente con lo anterior, se ha estimado que no pesa sobre el expropiante la obligación de notificar personalmente la gestión de consignación y solicitud de toma de posesión material al expropiado, pues no cobra aplicación en estos casos la regla del artículo 40 del Código de Procedimiento $\mathrm{Civil}^{73}$. Dicha notificación se verifica generalmente mediante avisos y en favor de todos los eventuales interesados, conforme al artículo 23 del decreto ley ${ }^{74}$.

Por otra parte, el procedimiento de consignación y toma de posesión material no considera la oposición contradictoria de los afectados ${ }^{75}$. La expropiación representa el ejercicio de una potestad pública ${ }^{76}$ y, como tal, irresistible para el expropiado ${ }^{77}$. Se trata de una atribución prevista constitucionalmente, autorizada por una ley por causas de utilidad pública o interés nacional y cuyo ejercicio se concreta a través de una actuación administrativa ${ }^{78}$.

71 De esta manera, se observa que el legislador ha entregado al expropiado la carga de acreditar su calidad de dueño y no al expropiante, como pudiera pensarse. Cfr. Morales Gana 1999, 15. 72 Ello explica, entre otros motivos, la adopción del acta de pleno No 87-2014 de la Corte Suprema de 17 de junio de 2014, que imparte instrucciones especiales en materia de giro de cheques en procedimientos de expropiación.

73 "A su turno, la resolución que tiene por efectuada la consignación fiscal de la compensación provisoria y por instado al expropiante de la toma de posesión material de la finca expropiada, contrariamente a lo sostenido por el oponente en este arbitrio, se debe notificar al expropiado y a terceros afectados por el acto administrativo en la forma que previene el inciso primero del artículo 23 del texto legal ya reseñado -y no personalmente como se pretende- [...]". Alzua Elizalde con Fisco de Chile (2010), considerando $14^{\circ}$.

74 Vid. Ponce Correa 2011, 215.

75 Para Ríos Álvarez el carácter no contencioso de la gestión de toma de posesión material deriva precisamente de la circunstancia de que no admite la oposición del expropiado o de terceros. Vid. Rios Álvarez 1978,76. Cabe advertir que Celis Danzinger sostiene una interpretación opuesta pues, a su juicio, procede conferir traslado al expropiado respecto de la solicitud de toma de posesión material con el fin de que este último pueda formular oposición o proceder a la recolección de frutos pendientes. Vid. Celis DANZINGER 2019, 934. Nos inclinamos por la postura expuesta por Ríos Álvarez, pues entendemos que la obligación de poner en conocimiento del expropiado y de terceros algunas actuaciones de este procedimiento, no implica conferirles traslado, a la vez que el derecho de solicitar la recolección de frutos pendientes, previsto en inciso $4^{\circ}$ del artículo 21 del Decreto Ley N².186, no constituye propiamente una oposición.

76 "[L]a potestad administrativa es un poder jurídico que comparte las características propias de todo el poder público estatal, del que la Administración del Estado forma parte, particularmente su sometimiento estricto al Derecho, su servicio a los intereses generales y su carácter unilateral y coactivo". Ferrada Bórouez 2007, 76.

77 "[...] Que, desde que el fundamento de la expropiación radica en la función social de la propiedad -función social que 'comprende cuanto exijan los intereses generales de la Nación, la seguridad nacional, la utilidad y la salubridad públicas y la conservación del patrimonio ambiental', conforme prescribe el inciso segundo del $N^{\circ} 24$ del artículo 19 de la Constitución-, lo que permite al Estado de modo excepcional privar del dominio de un bien a una persona, es indubitado que la primacía del interés general por sobre el particular del expropiado hace necesario prescindir de la voluntad de este último, quien no puede oponerse a la expropiación". Vid Sentencia TC Rol No 1038 (2008), considerando $14^{\circ}$.

78 Por esta razón afirma CALDERA Delgado que en el ejercicio de la potestad expropiatoria en Chile convergen necesariamente tres fuentes de grado diverso, de modo que éste jamás podría materializarse directamente en virtud de la ley. Cfr. Caldera Delgado 2001, 401. 
El pago y desposeimiento del expropiado son efectos inherentes del acto expropiatorio, de modo que la consignación y toma de posesión material constituyen diligencias que se enmarcan dentro de su natural ejecución. Así, quien pretenda oponerse a tales actuaciones debe necesariamente atacar la validez, vigencia o eficacia del acto administrativo que les sirve de sustento; no cabe simplemente negarse a ellas.

Ahora, según adelantamos en acápites anteriores, tal discusión corresponde ser formulada mediante el ejercicio de acciones previstas en el decreto ley o en otras normas, para cuya sustanciación se siguen procedimientos contenciosos, pero independientes a la gestión de consignación y toma de posesión material, de modo que por ello no se altera la naturaleza de la presente gestión.

Consecuentemente, la toma de posesión material no se paraliza por la sola interposición de un reclamo. Su eventual suspensión se enmarca en un ejercicio potestativo cautelar confiado al tribunal y que se desarrolla solo a partir de que el expropiado impugne la validez o vigencia del acto expropiatorio ${ }^{79}$.

\section{Posibilidad de defensa de los derechos e intereses del expropiado en el procedimiento de consignación y toma de posesión material}

Al comienzo del presente trabajo adelantamos que lo relevante de un procedimiento es que otorgue vías adecuadas de defensa a los involucrados, más allá de su definición como contencioso o voluntario. Tratándose la expropiación del ejercicio potestativo, la defensa de los afectados no pasa, desde luego, por discutir o negar la existencia de tal facultad estatal, sino por exigir el cumplimiento íntegro de los requisitos que la hacen procedente.

Así, la primera y quizá más importante garantía a los afectados por un proceso expropiatorio radica en que, cuando no existe acuerdo entre expropiante y expropiado, la ejecución del acto expropiatorio queda sometida a un control judicial forzoso. Ello, pues la Administración requiere de la intervención y autorización judicial para efectuar las dos diligencias más importantes: el pago provisional y la toma de posesión material ${ }^{80}$.

Dicha intervención judicial no se concibe como un acto de mero trámite, pues exige la concurrencia de ciertas condiciones esenciales: 1. la publicación del acto expropiatorio ${ }^{81} ; 2$. la consignación judicial del íntegro de la indemnización provisional82; 3. La publicación de la solicitud de consignación

\footnotetext{
79 Vid. Ponce Correa 2011, 277.

80 Incisos $4^{\circ}$ y $5^{\circ}, \mathrm{N}^{\circ} 24$ del artículo 19 de la Constitución e incisos $2^{\circ}$ y $3^{\circ}$ del artículo 21 del Decreto Ley $\mathrm{N}^{\circ} 2.186$.

81 Artículo $7^{\circ}$ del Decreto Ley $N^{\circ} 2.186$.

82 Inciso $5^{\circ}, \mathrm{N}^{\circ} 24$ del artículo 19 de la Constitución y artículo 20 del Decreto Ley N².186.
} 
y toma de posesión material83; y 4 . la inexistencia de solicitud de recolección de frutos pendientes ${ }^{84}$.

No obstante, es indudable que el procedimiento de consignación y toma de posesión material, en su carácter voluntario, ofrece un control judicial acotado, pues la intervención de los afectados o interesados es limitada; no se admite contradictor al interior del mismo ${ }^{85}$ y toda eventual oposición requiere el inicio de procedimientos contenciosos autónomos. Como control, opera siempre ante la ausencia de acuerdo, pero sin intervención del expropiado.

La posibilidad de plantear una oposición o formular otro tipo de discusiones jurídicas respecto del proceso expropiatorio existe, pero fuera de esta gestión voluntaria. El decreto ley prevé una serie de acciones, a las que se suman aquellas consagradas en la Constitución o leyes especiales. Para este trabajo, nos enfocaremos en revisar las dos vías de defensa que el numeral 24 del artículo 19 de la Carta ofrece en favor del expropiado.

La primera de ellas concierne a la acción de nulidad o reclamo de legalidad $^{86}$ del acto expropiatorio, la cual se tramita mediante juicio sumario ${ }^{87}$. Da origen a un contencioso en que intervienen ambas partes, no obstante, su ejercicio queda sujeto a dos importantes restricciones que pueden comprometer su eficacia ${ }^{88}$.

Debe ser deducida dentro de treinta días hábiles, contados desde la publicación del acto expropiatorio en el Diario Oficial ${ }^{89}$; ello marca una diferencia sustancial entre las partes, pues el expropiante, en cambio, goza de sesenta días hábiles para instar judicialmente por el desposeimiento ${ }^{90}$. Además, la demanda debe ser notificada dentro de los treinta días hábiles siguientes a su interposición, bajo apercibimiento de tenerse por desistida ${ }^{91}$.

Cabe observar que estas restricciones no están presentes en la acción de caducidad ${ }^{92}$, consagrada a nivel legal, la que también persigue el cese de efectos del acto expropiatorio. El término para ejercerla es de un año desde

83 Inciso $4^{\circ}$ del artículo 21 y artículo 23 del Decreto Ley $N^{\circ} 2.186$.

84 Inciso $5^{\circ}$ del artículo 21 del Decreto Ley $N^{\circ} 2.186$.

85 La única intervención del expropiado o terceros que la norma posibilita formular al interior de este procedimiento, en relación a la toma de posesión material, es la solicitud de recolección de frutos prevista en el artículo 21 inciso $5^{\circ}$ del decreto ley. No obstante, tal como anota Rios Álvarez, esta última no constituye realmente una oposición. Vid. Ríos Álvarez 1978, 76. Prevenimos que, no obstante, una opinión contraria aparece en CELIS DANZINGER 2019, 934.

${ }^{86}$ Letra a) del artículo $9^{\circ}$ del Decreto Ley $\mathrm{N}^{\circ} 2.186$.

87 Inciso $3^{\circ}$ del artículo $9^{\circ}$ del Decreto Ley $N^{\circ} 2.186$.

${ }^{88}$ No analizaremos aquí las restricciones que refieren a las causales de nulidad previstas en el decreto ley, pues ello atañe al aspecto sustantivo de esta acción y no al ámbito procesal que motiva el presente trabajo.

89 Artículo $9^{\circ}$ y 40 del Decreto Ley $N^{\circ} 2.186$.

90 Inciso $3^{\circ}$ del artículo 21 del Decreto Ley $N^{\circ} 2.186$.

91 Artículo $9^{\circ}$ inciso final de Decreto Ley $\mathrm{N}^{\circ} 2.186$.

92 Artículos 21, 33 y 34 del Decreto Ley N².186. 
que el expropiante incurre en la omisión que le sirve de fundamento y la notificación de la demanda no se sujeta a plazo. Así, resulta evidente que el legislador parece más llano a que se discuta la caducidad que la legalidad del acto ablatorio.

La segunda vía de defensa del expropiado consiste en reclamar el monto de la indemnización ${ }^{93}$. El plazo para deducir esta acción es más amplio, se extiende desde la publicación del acto expropiatorio hasta treinta días hábiles siguientes a la toma de posesión. Las críticas que usualmente se formulan atienden a lo poco regulado del procedimiento94, a que el expropiante también puede reclamar ${ }^{95}$ y al criterio para determinar la época de la desposesión ${ }^{96}$.

En cuanto a la competencia de los tribunales para ejercer tutela cautelar, esto es, adoptar medidas preventivas y provisionales, destinadas a dar efectividad material al expropiado respecto de la decisión ulterior definitiva de los asuntos controvertidos que este último plantee; en el caso de reclamar la procedencia del acto expropiatorio, está especialmente asegurada, tanto constitucional como legalmente, por la posibilidad de suspender la toma de posesión ${ }^{97}$.

El reclamo de la indemnización provisional, en cambio, no queda amparado por la hipótesis constitucional de suspensión del desposeimiento, pues la acción en este caso no ataca la procedencia del acto expropiatorio. Ahora, de todas formas, en esta materia no existe excepción a la aplicación de las reglas generales de tutela cautelar, de manera que los tribunales pueden adoptar medidas prejudiciales y precautorias comunes.

Por último, en cuanto al conocimiento del expropiado, advertimos que el decreto ley contempla diversas actuaciones para dar publicidad al proceso expropiatorio, pero la eficacia de la más importante, esto es, la notificación del acto expropiatorio, queda en entredicho. La norma prevé que ésta se ve-

\footnotetext{
93 Artículo 12 del Decreto Ley $N^{\circ} 2.186$.

94 Ríos Álvarez 1978, 113.

95 El Tribunal Constitucional se ha pronunciado al menos en dos ocasiones acerca de la inaplicabilidad del artículo 12, por otorgar legitimación activa al expropiante para reclamar de la indemnización provisional. Ambos reclamos fueron rechazados, entre otros motivos, por estimar dicho Tribunal que el procedimiento de determinación del monto provisorio se verifica de manera autónoma a la voluntad del expropiante. Vid. sentencias TC Roles Nº 4953 (2019) y Nº 5270 (2019).

96 La Corte Suprema estima que la toma de posesión material constituye una actuación de carácter jurídico y no fáctico, de modo que se verifica a partir de la resolución que la autoriza y no desde que se práctica efectivamente. Por este motivo, el plazo para deducir la acción de reclamo del monto debe contarse desde la resolución que autorizó la toma de posesión material y no desde el acta que da cuenta de haberse verificado materialmente. Vid. Sucesión López Díaz con SERVIU de Tarapacá (2009), considerandos $7^{\circ}$ y $9^{\circ}$.

97 Inciso $5^{\circ}, \mathrm{N}^{\circ} 19$ del artículo 24 de la Constitución e inciso $3^{\circ}$ del artículo $9^{\circ}$ del Decreto Ley $N^{\circ} 2186$. Ambas normas otorgan poder al juez que conoce del reclamo de procedencia del acto expropiatorio para decretar la suspensión del desposeimiento en mérito de los antecedentes que se hagan valer.
} 
rifique a través del Diario Oficial, un diario regional y Carabineros de Chile ${ }^{98}$; no obstante, en la práctica, solo la primera resulta efectivamente exigible ${ }^{99}$.

El conocimiento de parte del expropiado se verá reforzado posteriormente con la notificación de la solicitud de consignación y toma de posesión material, mediante sendas publicaciones en el Diario Oficial y un diario de circulación regional100. Más aún, al alero del tribunal, se podrán ordenar notificaciones de carácter cierto al expropiado, como personal o por cédula, y que la toma de posesión material sea intimada por un ministro de fe pública.

Es evidente que las publicaciones no aseguran el efectivo conocimiento al expropiado u otros sujetos, pero la cantidad de éstas y la realización de otras actuaciones de conocimiento al interior de la gestión voluntaria una vez que se inicia, a nuestro entender, otorgan razonables vías de información a los afectados.

Así, observamos una amplia posibilidad de ejercer la segunda vía de defensa constitucional antes mencionada, esto es, reclamar del monto de la indemnización. Ello, pues el plazo de ejercicio de esta acción se extiende hasta treinta días hábiles después del desposeimiento, de modo que la gestión voluntaria en estudio otorga a los afectados la oportunidad de tomar conocimiento oportuno y reunir los antecedentes necesarios para discutir el quantum.

No ocurre lo mismo con la nulidad del acto expropiatorio. $Y$ es que el término de treinta días hábiles para ejercer esta acción generalmente habrá vencido antes de que se inicie la gestión de consignación y toma de posesión; pues el expropiante goza del doble de plazo para instar por el desposeimiento. La gestión voluntaria no actúa en este caso como vía accesoria de conocimiento que facilite al expropiado reclamar la ilegalidad de la expropiación.

El conocimiento que el expropiado necesita adquirir para deducir esta acción dependerá, entonces, exclusivamente de la notificación del acto expropiatorio, actuación que, según mencionamos, se perfecciona por su sola publicación en el Diario Oficial. Este aviso constituye la única vía de comunicación garantizada al expropiado para estos efectos, siendo una de carácter general e inespecífico, que ofrece una baja oportunidad de conocimiento.

Por este motivo, la primera vía de defensa constitucionalmente asegurada al expropiado se encuentra, en nuestra opinión, dificultada en la práctica.

\footnotetext{
98 Artículo $7^{\circ}$ del Decreto Ley $N^{\circ} 2.186$.

99 Si bien la notificación del acto expropiatorio se concreta por medio de estas tres vías en forma copulativa, de acuerdo al artículo $7^{\circ}$ del Decreto Ley $N^{\circ} 2.186$, ésta se entiende perfeccionada "con la sola publicación del extracto en el Diario Oficial y su fecha será la de esa publicación". De esta manera, la publicación en el Diario Oficial constituye por sí suficiente notificación del acto ablatorio; la omisión de las otras dos gestiones podrá irrogar responsabilidad administrativa para los funcionarios encargados de ordenarlas, pero no confiere la posibilidad de retrotraer el procedimiento.

100 Artículo 23 del Decreto Ley N².186.
} 
Además de sujetarse la nulidad a restricciones de ejercicio mayores al de otras acciones, el decreto ley no exige que todas las vías de comunicación del acto expropiatorio se cumplan realmente; no asegura que el expropiado pueda tomar efectivo conocimiento del acto, en el tiempo previsto para reclamar su nulidad.

De esta manera, nos parece necesario instar por una revisión de las formas de notificación del acto expropiatorio, así como de aquellas restricciones a las que se sujeta la interposición del reclamo de legalidad, previstas en el Decreto Ley $N^{\circ} 2186$, con el fin de dotar de mayor efectividad la defensa del expropiado, reconocida constitucionalmente.

Dicho objetivo pudiera obtenerse por la vía de vincular el ejercicio de la acción de nulidad, o sujetar su caducidad, a actuaciones verificadas al interior de la gestión de consignación y toma de posesión material, tal como ocurre con otras acciones previstas del Derecho Ley 2186, de modo que las gestiones desarrolladas al interior de este procedimiento contribuyan al efectivo y oportuno conocimiento del expropiado.

\section{Conclusiones}

El proceso expropiatorio se regula esencialmente por el Decreto Ley Nº 2186 de 1978, norma esta última que prevé una fase administrativa y otra judicial. La etapa judicial se verifica a partir de procedimientos independientes, que se tramitan ante un mismo tribunal; la mayoría de ellos posee un carácter contencioso y eventual, aunque existe también una gestión voluntaria, cuya sustanciación, en cambio, resulta obligatoria cuando no existe acuerdo con el expropiado.

Dicha gestión se dispone para la realización de dos diligencias esenciales en la concreción de la expropiación: consignación de la indemnización provisional y toma de posesión material. Su carácter voluntario radica en que no exige el emplazamiento cierto del expropiado ni admite su intervención contradictoria pura y simple; cualquier oposición requiere el inicio de un nuevo procedimiento, que se sustancia independientemente.

La definición del procedimiento de consignación y toma de posesión material como voluntario no coloca al expropiado en un escenario de absoluta indefensión, pues ofrece la razonable posibilidad de tomar conocimiento y reclamar del monto de la indemnización provisional, e iniciar un procedimiento judicial contencioso.

No obstante, la posibilidad de impugnar el acto expropiatorio, especialmente cuando se trata de reclamar su legalidad, se encuentra dificultada de una manera considerable. Ello no deviene de la naturaleza voluntaria de la referida gestión, sino de la precaria notificación del acto expropiatorio, el breve plazo a que se sujeta el ejercicio de la acción de nulidad y la existencia de un plazo acotado para notificar el respectivo reclamo. 
A nuestro entender, esto último pudiera hacer conveniente revisar especialmente la forma de notificación del acto expropiatorio, así como las restricciones a las que se sujeta la interposición del reclamo de legalidad; objetivo que, tal vez, pudiera ser obtenido por la vía de vincular el ejercicio o caducidad de la acción de nulidad a alguna de las actuaciones verificadas en el seno de la gestión no contenciosa, para dotar al expropiado de mayores oportunidades de defensa.

\section{Bibliografía citada}

Actas oficiales de la Comisión de Estudio de la Nueva Constitución. Tomo VIII, sesiones $164^{\mathrm{a}}, 246^{\mathrm{a}}, 250^{\mathrm{a}}$ y $262^{\mathrm{a}}$. Disponible en: https://www.leychile.cl/Consulta/antecedentes_const_1980 [Fecha de consulta: 28 agosto 2019].

Aldunate Lizana, Eduardo (2006). Limitación y expropiación: Scilla y Caribdis de la dogmática constitucional de la propiedad. Revista Chilena de Derecho, vol. $33 \mathrm{~N}^{\circ} 2$, pp. 285-303.

Bermúdez Soto, Jorge (2014). Derecho administrativo general. Santiago, LegalPublishing Chile, $794 \mathrm{pp}$.

Biblioteca del Congreso Nacional (s/A). Historia del Decreto Ley No 2.186. Disponible en: https://www.bcn.cl/historiadelaley/nc/historia-de-la-ley/7576/ [Fecha de consulta: 27 agosto 2019].

Calamandrel, Piero (1996 [1944]). Instituciones de Derecho Procesal Civil (trad. Santiago Sentís Melendo). Buenos Aires, Librería El Foro, V I, 421 pp.

Caldera Delgado, Hugo (2001). Tratado de derecho administrativo. Santiago, Ediciones Parlamento Ltda., T II, 705 pp.

CAmacho Cepeda, Gladys (2019). Justicia administrativa y el derecho a la tutela jurisdiccional efectiva. Disponible en: https://doi.org/10.18601/21452946.n22.10 [Fecha de consulta: 6 enero 2020].

Carnelutti, Francesco (1973a [1956]). Instituciones del Proceso Civil (trad. Santiago Sentís Melendo). Buenos Aires, Ediciones Jurídicas Europa-América, V I, 557 pp.

(1973b [1956]). Instituciones del Proceso Civil (trad. Santiago Sentís Melendo). Buenos Aires, Ediciones Jurídicas Europa-América, V III, 467 pp.

Casarino Viterbo, Mario (1995). Manual de derecho procesal. Derecho procesal orgánico. Santiago, Editorial Jurídica de Chile, T I, 328 pp.

CASAS, Juan Alberto y Romero VillanueVa, Horacio J. (2014, reimpresión). Expropiación. Ley 21.499 comentada, anotada y concordada con las normas provinciales. Buenos Aires, Astrea, 264 pp.

CASSAgne, Juan Carlos (2002). Derecho administrativo. Buenos Aires, Abeledo-Perrot. T II, $662 \mathrm{pp}$.

CASTAN Tobeñas, José (1992). Derecho civil español, común y foral. Madrid, Reus S.A., T II vol. I, 761 pp.

Cea Egaña, José Luis (1988). Tratado de la Constitución de 1980. Santiago, Editorial Jurídica de Chile, 402 pp.

(2012). Derecho constitucional chileno. Santiago, Ediciones Universidad Católica de Chile, TII, 773 pp.

Celis Danzinger, Gabriel (2019). Manual de derecho administrativo general. Santiago, Editorial Hammurabi) $1162 \mathrm{pp}$.

Chiovenda, José (1977 [1923]). Principios de derecho procesal civil (trad. José Casais y Santaló, notas de Alfredo Salvador). Madrid, Reus S.A., T I, 767 pp.

Cordero QuinzacAra, Eduardo (2015). Declaración de utilidad pública y planes reguladores. Un problema sobre el contenido y las facultades del derecho de propiedad sobre el suelo. Revista de Derecho de la Pontificia Universidad Católica de Valparaíso XLIV, pp. 309-335. 
Correa Selamé, Jorge Danilo (2014). Derecho procesal orgánico. Santiago, Ediciones Jurídicas de Santiago, T I, 243 pp.

(2016). El abandono del procedimiento (doctrina- jurisprudencia). Santiago, Ediciones Jurídicas de Santiago), 406 pp.

Cortez Matcovich, Gonzalo (2013). Segunda parte. La fase de discusión. En: Cortez Matcovich, Gonzalo [coord.], Proceso civil. El juicio ordinario de mayor cuantía, Santiago, Thomson Reuters, pp. 97-171.

Couture, Eduardo J. (2007). Fundamentos del Derecho Procesal Civil. Montevideo, Editorial $B$ de F, 424 pp.

Evans DE LA CuADRA, Enrique (1999). Los derechos constitucionales. Santiago, Editorial Jurídica de Chile, T III, 463 pp.

De PINA, Rafael (1936). Manual de derecho procesal civil. Madrid, Reus S.A., 592 pp.

Dougnac Rodríguez, Antonio (1994). Manual de derecho indiano. México D.F., Universidad Nacional Autónoma de México, 456 pp.

Drago, Mariano J. (1949). El poder de expropiación y sus límites constitucionales. Buenos Aires, Colegio de Abogados de Buenos Aires, 24 pp.

Fermandois V., Arturo (2010). Derecho constitucional económico. Santiago, Ediciones Universidad Católica de Chile, T II, 488 pp.

Fernández de Buján, Antonio (2001). La jurisdicción voluntaria. Madrid, Civitas, 224 pp.

Fernández-Treguerres García, Ana (1996). Un supuesto de jurisdicción voluntaria notarial: El acta de notoriedad para la declaración de herederos abintestato. En: Diez-Picazo GiméNEZ, Ignacio y MARTíneZ-SimAnCAS y SÁNCHEZ, Julián [dir.], Estudios sobre derecho procesal, Madrid, Sopec Editorial, V 3, pp. 3882-3907.

Ferrada Bórquez, Juan Carlos (2007). Las potestades y privilegios de la administración pública en el régimen administrativo chileno. Revista de Derecho (Valdivia), Vol. XX - N², pp. 69-94.

Figueroa Yávar, Juan Agustín y Morgado San Martín, Erika (2013). Procedimientos civiles e incidentes. Santiago, Thomson Reuters, 420 pp.

Fuentes Olmos, Jessica (2018). El derecho de propiedad. Santiago, DER Ediciones, 490 pp.

Gerona Peña, Gonzalo (1996). "La jurisdicción voluntaria en el ámbito notarial y registral" en: Diez-Picazo Giménez, Ignacio y Martínez-Simancas y Sanchez, Julián [Dir.], Estudios sobre derecho procesal (Madrid, Sopec Editorial) V 3, pp. 3909-3960.

GonzÁlez PovedA, Bienvenido (2008). La jurisdicción voluntaria. Doctrina y formularios. Navarra, Thomson Aranzadi (actualizada por Pedro González Poveda y Jorge González Rodríguez), 1829 pp.

GuILOFF TITIUN, Matías (2018). La expropiación regulatoria: Una doctrina impertinente para controlar la imposición de límites al derecho de propiedad privada en la Constitución chilena. Revista lus et Praxis, año 24, N² 2, 2018, pp. 621-648.

Hoyos Henrechson, Francisco (2001). Temas fundamentales de derecho procesal. Santiago, Conosur (actualización de María Teresa Hoyos de la Barrera) 281 pp.

Biblioteca Del Congreso Nacional (s/a). Informe Secretaría de Legislación, 14 de octubre de 1977. Historia del Decreto Ley N².186. Disponible en: https://www.bcn.cl/historiadelaley/nc/historia-de-la-ley/7576/ [Fecha de consulta: 27 agosto 2019].

Jiménez Larraín, Fernando y Jiménez Looslı, Fernando (2014). Derecho constitucional. Concepción, Universidad Católica de la Santísima Concepción, T I, 510 pp.

Lillo HunzinKer, Lenin (2012). Manual de derecho procesal civil. Santiago, Ediciones Jurídicas de Santiago, TI, $261 \mathrm{pp}$.

LÓPEZ-Nieto y MAYO, Francisco (2007). Manual de expropiación forzosa y otros supuestos indemnizatorios. Madrid, El consultor de los Ayuntamientos, 836 pp.

LOZANO CORBI, Enrique (1995). ¿Existió en la época republicana romana el derecho a la expropiación forzosa por causa de utilidad pública? Revista de Estudios Histórico-Jurídicos [Sección Derecho Romano], XVII, pp. 123-129.

Malorano, Jorge Luis (1978). La expropiación en la ley 21.499. Buenos Aires, Cooperadora de Derecho y Ciencias Sociales, 237 pp. 
Marienhoff, Miguel S. (1998). Tratado de derecho administrativo. Buenos Aires, Abeledo Perrot, T IV, 889 pp.

Matute E., Claudio (2014). Expropiaciones regulatorias. Aplicabilidad al caso chileno. Santiago, Thomson Reuters LA LEY, 226 pp.

Montory BARriga, Gonzalo Javier (2019). La propiedad constitucional: Limitaciones, privaciones, contenido esencial. Valencia, Tirant lo Blanch, 233 pp.

Morales Gana, Sylvia (1999). Procedimientos judiciales vinculados a las expropiaciones decretadas por el Ministerio de Obras Públicas. Santiago, Consejo de Defensa de Estado, 49 pp.

Navarro Beltrán, Enrique (2016). La Constitución económica chilena ante los tribunales de justicia. Santiago, Ediciones Universidad Finis Terrae, 313 pp.

Nogueira Alcalá, Humberto (2013). Derechos fundamentales y garantías constitucionales. Santiago, Librotecnia, T IV, 361 pp.

Núñez Ojeda, Raúl y Pérez Ragone, Álvaro (2013). Manual de derecho procesal. Parte general. Santiago, Thomson Reuters, 486 pp.

Orellana Torres, Fernando (2008). Manual de derecho procesal. Santiago, Librotecnia, T I, $342 \mathrm{pp}$.

Peñallillo Arévalo, Daniel (1995). La expropiación ante el derecho civil. Santiago, Editorial Jurídica de Chile, 250 pp.

Peña Mardones, Cristóbal, (2011). Algunas consideraciones acerca de las acciones de reclamación por expropiación. Revista de Derecho. Consejo de Defensa del Estado, año 2, No 4, Santiago de Chile, 2001, pp. 31-77.

Pereira Anabalón, Hugo (1993). Curso de derecho procesal. Santiago, Editorial Jurídica Conosur, T I, 480 pp.

Ponce Correa, Patricio (2011). La expropiación en su manifestación judicial. Santiago, Librotecnia, 499 pp.

Ponce de león Salucci, Sandra (2015). Expropiación vs. limitación al dominio desde la perspectiva de la indemnización. En: Henríquez Viñas, Miriam y Silva Gallinato, María Pía [coord.], La Constitución económica, Santiago, Thomson Reuters La Ley, pp. 293-324.

PonTE, V. (2008). Régimen jurídico de las vías públicas en derecho romano. Madrid, Dykinson, 302 pp.

Quezada Meléndez, José (1984). Derecho procesal civil chileno. La jurisdicción. Santiago, Ediar Editores Ltda., 417 pp.

Quezada Rodríguez, Flavio (2018). Bases constitucionales de la expropiación. En: HenríQuez Viñas, Miriam y Rajevic Mosler, Enrique [coord.], Derecho de propiedad. Enfoques de derecho público. Santiago, Der Ediciones, pp. 87-122.

REYNolds, Susan (2010). Before Eminent Domain. Toward a History of Expropriation of Land for the Common Good. Chapel Hill, N.C., University of North Carolina Press, 175 pp.

Romero Seguel, Alejandro (2015). Curso de derecho procesal civil. De los actos procesales y sus efectos. Santiago, Thomson Reuters, T III, 192 pp.

(2017). Curso de derecho procesal civil. De los actos procesales y sus efectos. Santiago, Thomson Reuters, T IV, $241 \mathrm{pp}$.

Ríos Álvarez, Lautaro (1978). Estudio de la ley orgánica de procedimiento en la expropiación. Valparaíso, Edeval, 122 pp.

SATTA, Salvatore (1971 [1968]). Soliloquios y coloquios de un jurista (trad. Santiago Sentís Melendo). Buenos Aires, Ediciones Jurídicas Europa-América, 545 pp.

Silva Cimma, Enrique (1995). Derecho administrativo chileno y comparado. Actos, contratos y bienes. Santiago, Editorial Jurídica de Chile, 336 pp.

Sото Kloss, Eduardo (1996). Derecho administrativo. Bases fundamentales. Santiago, Editorial Jurídica de Chile, TI, 359 pp.

ValdiviA, José Miguel (2018). Manual de derecho administrativo. Valencia, Tirant lo Blanch, 448 pp.

Verdugo Marinkovic, Mario, Pfeffer Urquiaga, Emilio y Nogueira Alcala, Humberto (2002). Derecho constitucional chileno. Santiago, Editorial Jurídica de Chile, T I, 375 pp.

Véscovi, Enrique (2006). Teoría general del proceso. Bogotá, Editorial Temis, 388 pp. 
Vivanco Martínez, Ángela (2006). Curso de derecho constitucional. Aspectos dogmáticos de la Carta Fundamental de 1980. Santiago, Ediciones Universidad Católica de Chile, T II, $555 \mathrm{pp}$.

\section{Normas jurídicas citadas}

Decreto Ley N 1552, Acta Constitucional N 3, De los derechos y deberes constitucionales. Diario Oficial, 13 septiembre 1976.

Decreto $N^{\circ} 100$, que fija el texto refundido, coordinado y sistematizado de la Constitución Política de la República de Chile. Diario Oficial, 22 septiembre 2005.

Ley $\mathrm{S} / \mathrm{N} ; 14$ agosto 1838.

Ley $\mathrm{S} / \mathrm{N}$; 18 junio 1857.

Ley No 1552, Código de Procedimiento Civil. Diario Oficial, 30 agosto 1902.

Ley $N^{\circ} 19903$, sobre procedimiento para el otorgamiento de la posesión efectiva de la herencia y adecuaciones de la normativa procesal, civil y tributaria sobre la materia. Diario Oficial, 10 octubre 2003.

Decreto Ley $N^{\circ} 2186$, aprueba ley orgánica de procedimiento de expropiaciones. Diario Oficial, 9 junio 1978.

Ley $N^{\circ} 18097$, Orgánica constitucional sobre concesiones mineras. Diario Oficial, 21 enero 1982.

Ley N ${ }^{\circ}$ 18575, Orgánica Constitucional de Bases Generales de la Administración del Estado. Diario Oficial, 05 diciembre 1986.

Ley $N^{\circ} 18932$, Sustituye el inciso segundo del artículo $4^{\circ}$ del Decreto Ley $N^{\circ} 2186$, de 1978. Diario Oficial, 10 febrero 1990.

Ley No 18705, Introduce modificaciones a los Códigos de Procedimiento Civil, de Procedimiento Penal, Orgánico de Tribunales, del Trabajo y al Decreto Ley N²876, de 1979. Diario Oficial, 24 mayo 1988.

Ley $N^{\circ} 19880$, Establece bases de los procedimientos administrativos que rigen los actos de los órganos de la Administración del Estado. Diario Oficial, 29 mayo 2003.

Ley $N^{\circ}$ 20192, Modifica diversas disposiciones del Código de Procedimiento Civil. Diario Oficial, 26 junio 2007.

Ley $N^{\circ} 20791$, Sobre procedimiento para el otorgamiento de la posesión efectiva de la herencia y adecuaciones de la normativa procesal, civil y tributaria sobre la materia. Diario Oficial, 10 octubre 2003.

Ley $N^{\circ}$ 20886, Modifica el Código de Procedimiento Civil, para establecer la tramitación digital de los procedimientos judiciales. Diario Oficial, 18 junio 2016.

Ley No 20791, Modifica la Ley General de Urbanismo y Construcciones en materia de afectaciones de utilidad pública de los planes reguladores. Diario Oficial, 29 octubre 2014.

Ley N ${ }^{\circ} 21180$, Transformación digital del Estado. Diario Oficial, 11 noviembre 2019.

Decreto 2651 del Ministerio de Fomento, que aprueba Reglamento de Expropiaciones para Obras Públicas. Diario Oficial, 11 octubre 1934.

\section{Jurisprudencia citada}

Sucesión Benjamín Mucientes Morales con Fisco de Chile (2003): Corte Suprema, 28 mayo 2003.

Inversiones Piedra Roja Limitada con Fisco de Chile (2005): Corte suprema, 14 junio 2005.

Sucesión López Díaz con SERVIU de Tarapacá (2009): Corte Suprema 29 octubre 2009.

Alzua Elizalde con Fisco de Chile (2010): Corte Suprema, 30 septiembre 2010.

Bedoya Herrera Jorge Eduardo Gonzalo con Serviu Metropolitano (2013): Corte Suprema, 16 abril 2013.

Solicitante: Banco Santander Chile (2013): Corte Suprema, 17 abril 2013.

Muñoz Ayamante Víctor Hugo (2014): Corte de Apelaciones de Coihaique, 3 abril 2014.

Solicitante Ilustre Municipalidad de Estación Central (2014): Corte Suprema, 14 agosto 2014 . 
Landerretche Diaz y otros con Luis Zegpi Jimenez (2015): Corte Suprema, 20 mayo 2015. José Ugalde Vásquez con Servicio de Vivienda y Urbanización de la Región del Bío Bío (2016): Corte Suprema, 6 abril 2016.

Velásquez Carreño con Fisco de Chile (2015): Corte Suprema, 1 junio 2015.

\section{Tribunal Constitucional}

Sentencia TC Rol No 552 (2008): Tribunal Constitucional, 11 marzo 2008.

Sentencia TC Rol No 1038 (2008): Tribunal Constitucional, 14 agosto 2008.

Sentencia TC Rol No 1576 (2010): Tribunal Constitucional, 16 diciembre 2010.

Sentencia TC Rol No 2900 (2017): Tribunal Constitucional, 21 marzo 2017.

Sentencia TC Rol No 3008 (2016): Tribunal Constitucional, 27 diciembre 2016.

Sentencia TC Rol No 3302 (2017): Tribunal Constitucional, 9 noviembre 2017.

Sentencia TC Rol No 4953 (2019): Tribunal Constitucional, 8 octubre 2019.

Sentencia TC Rol No 5257 (2019): Tribunal Constitucional, 11 junio 2019.

Sentencia TC Rol No 5270 (2019): Tribunal Constitucional, 8 octubre 2019.

Sentencia TC Rol N 5937 (2019): Tribunal Constitucional, 17 julio 2019. 